\title{
The spatial distribution of sago palm landscape Sentani watershed in Jayapura District, Papua Province, Indonesia
}

\author{
PETRUS ABRAHAM DIMARA ${ }^{1,2, \boldsymbol{v}}$, RIS HADI PURWANTO ${ }^{3}$, SIGIT SUNARTA ${ }^{4}$, WAHYU WARDHANA ${ }^{3}$ \\ ${ }^{1}$ Program of Forestry, Graduate School, University of Gadjah Mada J1. Agro No. 1, Bulaksumur, Sleman 55281, Yogyakarta, Indonesia \\ ${ }^{2}$ Departement of Forestry, Faculty of Forestry, University of Papua. Jl. Gunung Salju Amban, Manokwari 98312, West Papua, Indonesia. Telp: \\ +6281344614712, `email: p.dimara@unipa.ac.id \\ ${ }^{3}$ Departement of Forestry Management, Forestry Faculty, University of Gadjah Mada J1. Agro No. 1, Bulaksumur, Sleman 55281, Yogyakarta, Indonesia \\ ${ }^{4}$ Departement of Forest Products Technology. Forestry Faculty, University of Gadjah Mada J1. Agro No. 1, Bulaksumur, Sleman 55281, Yogyakarta, \\ Indonesia
}

Manuscript received: 12 July 2021. Revision accepted: 22 August 2021.

\begin{abstract}
Dimara PA, Purwanto RH, Sunarta S, Wardhana W. 2021. The spatial distribution of sago palm landscape Sentani watershed in Jayapura District, Papua Province, Indonesia. Biodiversitas 22: 3811-3820. Sago palm is one of the starch sources used as local food in Papua, therefore this research aims to identify the supporting environment for the plant to grow by utilizing spatial data. The methods used were Spatial Analysis and Field Survey, where the first employed satellite imagery of Quickbird in 2012 and Landsat 8 in 2020 to distinguish between sago and non-sago palm landscape. In the process, five parameters were used, consisting of covering land elevation, slope gradient, soil type, rainfall as well as the optimal distance from the river and lake. The result showed the sago palm landscape in Sentani Watershed lies in the elevation of $0-450 \mathrm{~m}$ asl, while its largest habitat which lies between $0-100 \mathrm{~m}$ asl covering an area of $4,385.63$ is found in a flat slope covering an area of 2,941.99 ha and in a very steep slope that spreads out over 41.92 ha. Generally, in Sentani Watershed, the plant grows in Mediterranean soil possessing thick solum with $\mathrm{pH}$ 5.0-7.0 and medium to great soil erodibility. Moreover, the largest habitat experiences a precipitation rate of $1,750 \mathrm{~mm} \mathrm{yr}^{-1}$ covering a total of $6,846.24$ ha, while the Doyo River has the largest sago palm landscape compared to other rivers.
\end{abstract}

Keywords: Elevation, Metroxylon sagu, sago palm habitat, Sentani watershed, slope gradient

\section{INTRODUCTION}

Sago palm (Metroxylon sagu Rottb.) is one of the main edible staple starch sources which has become a part of local cultures in Papua and West Papua provinces of Indonesia (Yater et al. 2019). This is a type of plant that naturally grows in a river basin, freshwater \& peat swamp, dry land, temporarily and permanently waterlogged land, as well as around water sources (Yamamoto 2011; Matatula et al. 2019). It can also be found at an altitude of $1,250 \mathrm{~m}$ asl with precipitation of $4,500 \mathrm{~mm} \mathrm{yr}-1$ including areas having high precipitation and moisture rate. The suitable environment for the plant to grow is a muddy area that supports non-submerged pneumatophore (breathing roots) while being rich in minerals, organic matters, and slightly acidic brownish groundwater. Sago palm is durable in certain conditions like drought, flood, strong wind, and fire (Ehara et al. 2018), hence its growth and productivity are suggested to be affected by environmental factors (Muhidin et al. 2016).

Furthermore, the two aforementioned provinces have sago palm landscapes covering 1.2 million ha (Yater et al. 2019), making Jayapura District to possess great potential for this plant's presence (Abbas et al. 2020; Riyanto et al. 2018). Some research state sago varieties surrounding Sentani Lake in Papua contain high starch, namely phara, yebha, osukul, and folo (Yamamoto 2011; Matanubun 2015). The starch extracted from the Yebha variety is 7.60-
7.9 tons $\mathrm{ha}^{-1} \mathrm{yr}^{-1}$ and 8.30 ton $\mathrm{ha}^{-1} \mathrm{yr}^{-1}$ is from Phara (Yamamoto 2011). Sago is considered as one of the local food assets, while the high carbohydrate content can be selected as the world's alternative in facing the crisis related to this nutrient type (Zhu 2019). In addition, the palm grows naturally in the Jayapura and has been equally utilized by the local community for generations. However, the man-made sago cultivation initiative is still less important and in reality, the Sentani sub-district establishment has aggravated the situation. Due to this regional partition, lots of sago forests surrounding Sentani Lake have been converted to built-up areas and agricultural fields. Human activities are one of the main driving forces of land use and cover changes in natural environments generally (Spruce et al. 2020; Xu et al. 2020). Hence, to determine the latest exact land coverage, sago palm landscape needs to be mapped in the district.

Moreover, geographical information system and remote sensing are types of technology that provides the latest maps of particular vast areas rapidly, easily and less expensively (Warnasuriya et al. 2014; Sulistyo 2017; Birhane et al. 2019). Information on the landscape, climate parameter, soil, and hydrology can be used to develop an environmental spatial model for sago palm's growing place. Therefore, this research aims to examine the identification of the plant's environment by using spatial data that are integrated with field inventory to provide deeper information on the respective habitat. 


\section{MATERIALS AND METHODS}

\section{Time and location of research}

This research was conducted from August to December 2020 in several locations where the sago palm landscape covers the Sentani Watershed area (DAS Sentani) and the GIS laboratory of the Faculty of Forestry, University of Papua. Administratively, the landscape spreads over 6 (six) Sub-Districts i.e. Sentani, Ebungfau, Kemtuk, East and West Sentani, as well as Waibu in Jayapura District. Geographically, the mentioned Watershed lies between $2^{0} 27^{\prime} 46.88^{\prime \prime}-2^{0} 44^{\prime} 7.95^{\prime \prime} \mathrm{S}$ and $140^{\circ} 16^{\prime} 44.76^{\prime \prime}$ $140^{0} 38^{\prime} 25.37^{\prime \prime} \mathrm{E}$.

\section{Procedures}

Two types of satellite imageries were used, namely Quickbird in 2012 and Landsat 8 in 2020, to differentiate between sago and non-sago palm landscapes. Remote sensing (RS) and Geographic Information Systems (GIS) have emerged as effective tools for mapping and monitoring land cover over a period of time (Saadat et al. 2011; USGS 2017). Hence, the imageries were processed with Envi 4.5 to create a multispectral and supervised classification for land coverage. Supervised image classification was performed by using the Maximum likelihood algorithm as one of the popular techniques of this process (Osunmadewa et al. 2018; Kumar et al. 2021). The accuracy test applied through the Kappa coefficient was conducted using a confusion or error matrix to compare the relationship between known field data and the classification results. Data regarding the sago palm were obtained, then processed with ArcGIS 10.8 to calculate the landscape coverage. These were needed to figure out the biophysical condition of the plant's habitat in Sentani Watershed's natural forests. Spatial analysis, a method comprised of several calculations and logical evaluations (mathematical), was used to determine relation potentials or (possible) patterns having geographical features including digital data in certain regional borders (Kindu et al. 2013; Liu et al. 2020). Fieldwork or survey was also carried out to check the presence of sago palm in its habitat based on the spatial model result, by examining the diameter of a circular plot following the plant's cluster. The plot was selected according to sago palm's growth in cluster form, while its position was set systematically on 15 designed sample points. Besides, the measurement of temperature and humidity with thermohygrometer, as well as sunlight intensity using lux meter, was done inside and outside the sago grove. The data used and their types can be seen in Table 1.

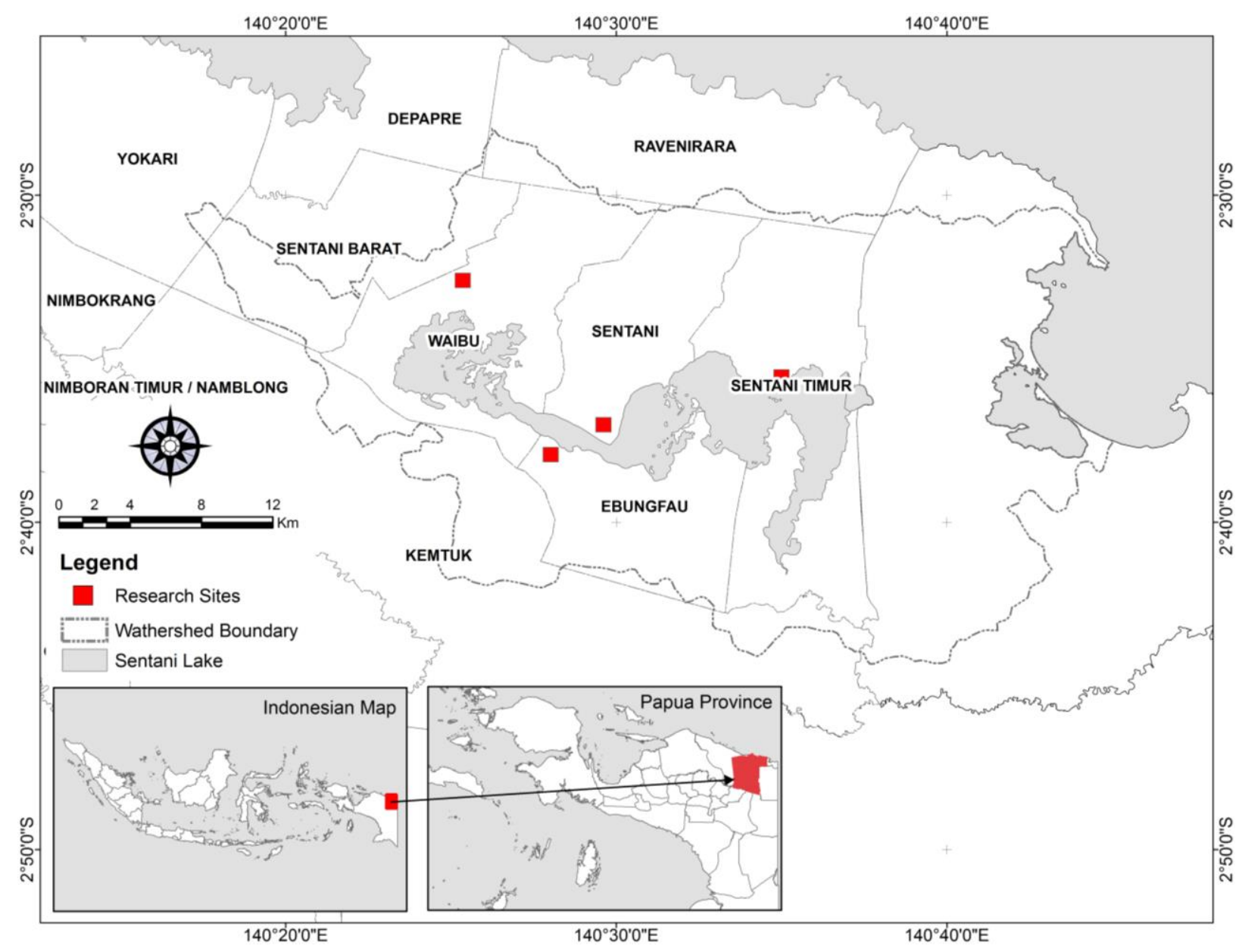

Figure 1. Map of sago forest research in Sentani Watershed, Jayapura District, Papua, Indonesia 
Table 1. The research spatial data

\begin{tabular}{lll}
\hline Data & $\begin{array}{l}\text { Types } \\
\text { of data }\end{array}$ & Source \\
\hline Indonesian Topography & Vector & BIG \\
$\begin{array}{l}\text { Quickbird Multispectral } \\
\text { Landsat 8 }\end{array}$ & $\begin{array}{l}\text { Raster } \\
\text { Raster }\end{array}$ & BIG \\
$\begin{array}{l}\text { Earthexplorer.usgs.gov } \\
\text { Mission (SRTM). }\end{array}$ & Raster & Earthexplorer.usgs.gov \\
Sago Palm Landscape & Vector & Supervised \\
& & classification \\
Soil type & Vector & BIG, Bappeda Papua \\
Elevation (DEM) & Vector & Earthexplorer.usgs.gov \\
Slope & Raster & TIN, IDW, Kriging \\
Rivers & Vector & Bappeda Papua \\
Rain Precipitation & Vector & Thiessen polygon method \\
Watershed area & Vector & Departement of foretsry \\
Jayapura administration & Vector & Bappeda Papua \\
\hline
\end{tabular}

\section{Data analysis}

The thematic map overlay method combined with the fieldwork and statistic analysis was used to assess the sago palm habitat's suitability. Based on this, 5 (five) environmental parameters i.e. elevation, slope gradient/ inclination, soil types, rainfall, and optimal distance of river and lake were considered. Biophysical and biochemical traits are useful for estimating plant growth and yield (El-Hendawy et al. 2019). Therefore, data analysis was carried out by overlaying the spatial and field data, while the suitable area for the sago palm was analyzed by tabulation. The GIS overlay technique applied to ecological and environmental research has shown its usefulness in understanding and managing land suitability (BenDor et al. 2017).

Further analysis was carried out to obtain elevation and slope data which were derived from the Indonesian Topographic Map (RBI) with a scale of 1:250,000 published by the Geospatial Information Agency (Badan Informasi Geospatial). For more illustration, the map of land elevation was extracted from contour data analysis with a contour interval of 50 metres, then classified into 6 classes, leading to the grouping of sago palm habitat into plain, hill, and mountain. In addition, the maps of slope gradient were based on contour data through interpolation analysis to decrease slope (\%), then classified into 6 classes which put the habitat into the following categories: Flat/No slope $(0-1 \%)$, gentle slope $(2-8 \%)$, slopy (9-15\%), slightly steep $(16-25 \%)$, steep $(26-40 \%)$, very steep (41-60\%) and extremely steep (>60\%) (Wondie et al. 2012; Li et al. 2020).

Similarly, maps of soil types were derived from the Map with a scale of 1:250,000 published by the Centre of Soil Research and Agroclimate (Puslitanak). Sago palm grows in varied soil types, hence the habitats are categorized based on suborder/great group. Then precipitation was measured by grouping according to the total annual rainfall $\left(\mathrm{mm}\right.$ year $\left.{ }^{-1}\right)$, where the data used were from BMKG, Jayapura in 2018. Precipitation data management in GIS uses the Thiessen polygon method to divide areas that have the same rainfall. However, buffering analysis was used to calculate the distance from the river or lake to the sago palm landscape $(200 \mathrm{~m})$.

\section{RESULTS AND DISCUSSION}

Sago palm (Metroxylon sagu Rottb) in Sentani Watershed, Jayapura District grows naturally in form of large and small clusters. In its vernacular names among the local community of Sentani, this plant is classified based on morphological features into several varieties e.g. folo, hobolo, mano, phane, phara, rondo, ruruna, usukhulu, wani and yebha (Yamamoto 2011; Matanubun 2015). The data analysis result showed the sago palm landscape covers $7,842.76$ ha and this scatters in 6 sub-districts i.e. Ebungfau (899.53 ha), Kemtuk (593.30 ha), Sentani (2,164.61 ha), West Sentani (696.01 ha), East Sentani (1,521.85 ha), and Waibu (1,967.46 ha), which can be seen in Figure 2 .

\section{Sago habitat based on elevation}

The classification of sago landscape elevation in Sentani Watershed covers highland, low-land, and wetland forests (swamp and lake), as well as Hills, which can be seen in Table 2 and Figure 3.

Sago palm landscape in the research site lies in the elevation of $0-450 \mathrm{~m}$ asl, while its largest habitat can be seen at $0-100 \mathrm{~m}$ asl covering 4,385.63 ha (55.92\%). Based on the growth observation, sago palm adapts and grows well at 0-100 $\mathrm{m}$ asl, but some scholars said it grows optimally at 0-400 m (Bantacut 2011; Ehara et al. 2018). Meanwhile, the plant's smallest habitat scatters between $401-450 \mathrm{~m}$ asl and covers 11.39 ha $(0.15 \%)$. The best suitable elevation for sago palm to grow and have great starch content is $400 \mathrm{~m}$ asl, therefore any level higher than this causes poor growth and less amount of starch. Altitude affects the reception of sunlight for the process of photosynthesis in the plant (Miyazaki et al. 2007)

From the field observation at a $100 \mathrm{~m}$ asl, clusters of sago palm grow in a great number in varied habitats, namely temporarily and permanently waterlogged, as well as dry land surrounding Sentani lakeside. Furthermore, the shore acts as the fertile ground for sago palm as this area is relatively flat and has a constant water supply. The plant can also be found in river banks and around the water source(s) including any high-water-containing land and /or waterlogged areas (Anugoolprasert et al. 2012). 


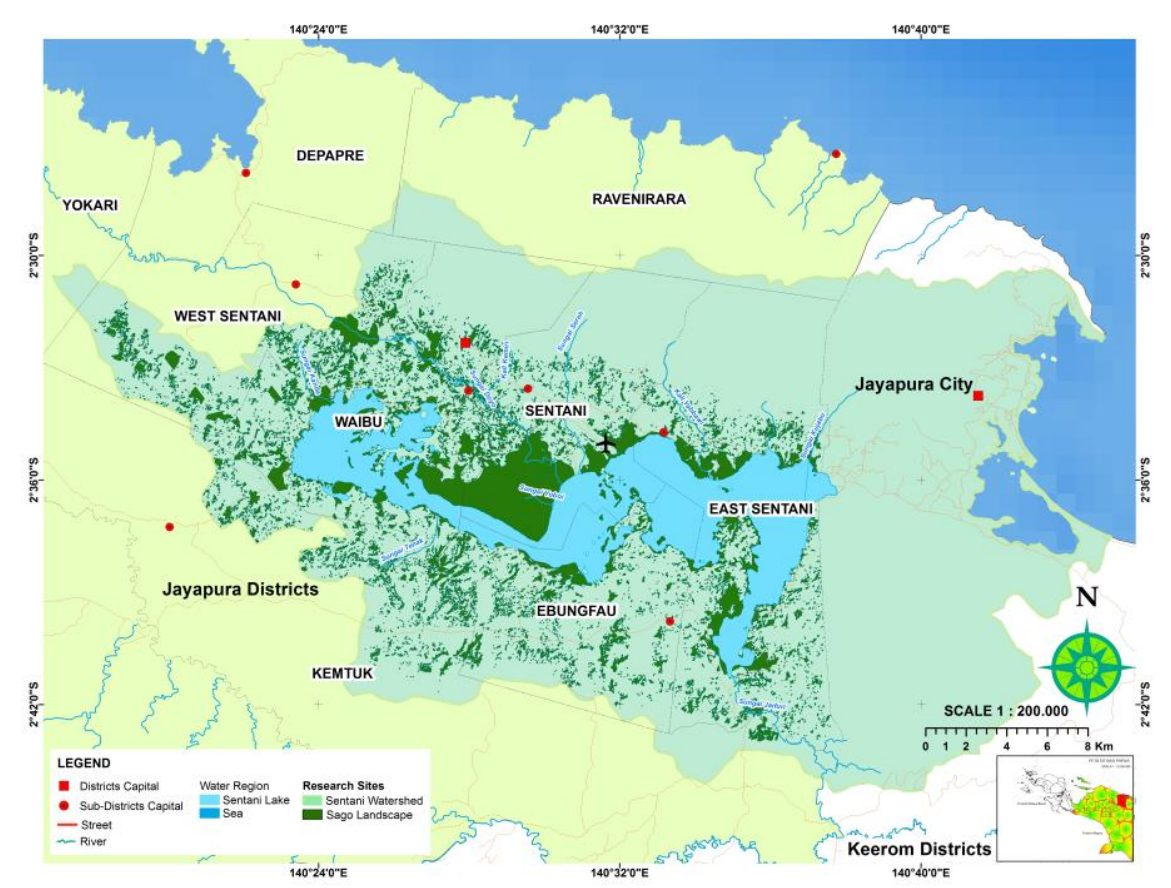

Figure 2. Map of the distribution of sago landscape per sub-district

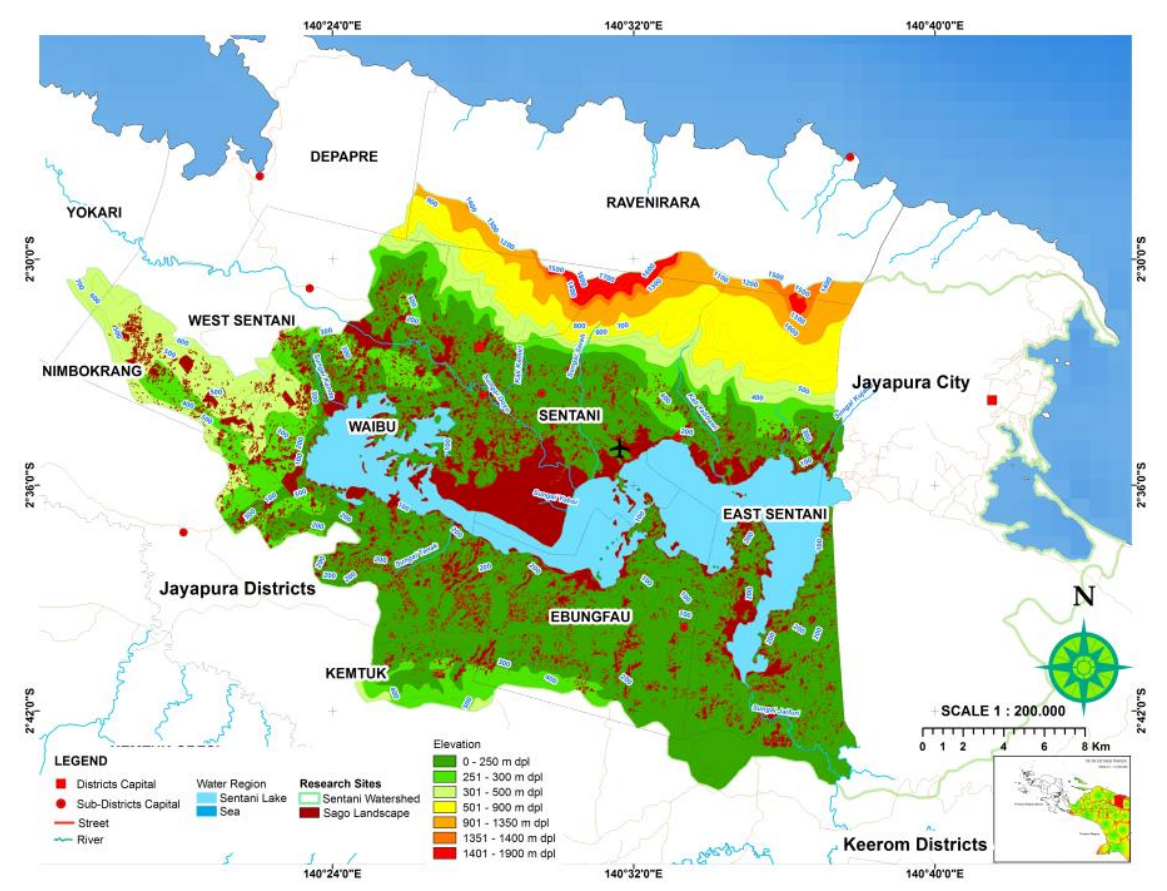

Figure 3. Map of sago palm landscape based on elevation

Table 2. Elevation-based distribution of sago palm landscape

\begin{tabular}{|c|c|c|c|c|c|c|c|c|}
\hline \multirow{2}{*}{$\begin{array}{c}\text { Elevation } \\
(\mathrm{m} \text { asl })\end{array}$} & \multicolumn{6}{|c|}{ Sub-district (ha) } & \multirow{2}{*}{ Total } & \multirow{2}{*}{ Percent (\%) } \\
\hline & Ebungfau & Kemtuk & Sentani & West Sentani & East Sentani & Waibu & & \\
\hline $0-100$ & 346.24 & 86.30 & 2015.36 & 44.66 & 829.25 & 1063.82 & $4,385.63$ & 55.92 \\
\hline $101-150$ & 17.04 & - & 101.78 & 45.33 & 82.62 & 180.01 & 426.78 & 5.44 \\
\hline $151-200$ & 385.99 & 285.80 & 26.46 & 170.3 & 541.93 & 330.14 & $1,740.62$ & 22.19 \\
\hline $201-250$ & 130.25 & 111.86 & - & - & 23.28 & 14.03 & 279.41 & 3.56 \\
\hline $251-300$ & 20.03 & 81.44 & 14.19 & 151.38 & 41.50 & 281.41 & 589.95 & 7.52 \\
\hline $301-350$ & - & 4.38 & 6.82 & 2.68 & 3.25 & 6.62 & 23.75 & 0.30 \\
\hline $351-400$ & - & 23.52 & - & 270.27 & - & 91.46 & 385.25 & 4.91 \\
\hline $401-450$ & - & - & - & 11.39 & - & - & 11.39 & 0.15 \\
\hline Total & 899.53 & 593.30 & $2,164.61$ & 696.01 & $1,521.85$ & $1,967.46$ & $7,842.76$ & 100.00 \\
\hline
\end{tabular}

Source: Spatial Data Analysis (2020) 
Different land elevations and temperatures have related influences. Sago palms in the upland (>100 m asl) usually form small clusters which live close to the dry land and other woody vegetation especially in the river banks, water source, and valley that has runoff flows during rainy days. This causes not growing up to the full potential, because the plants compete with one another to absorb nutrients, water, and sunlight. Sago palm grows in any land that has an elevation ranging from $0-700 \mathrm{~m}$ asl, yet found at 1,000 $\mathrm{m}$ asl (Lim and Chung 2020).

The elevation is also linked to the temperature difference of day and night, while in the vast area, elevation and slope direction influence the local microclimate. Moreover, sunlight is essential for plants to grow by affecting their physiology process especially photosynthesis. Some factors influencing sago palm photosynthesis are light intensity, temperature, and $\mathrm{CO}_{2}$ concentration (Azhar et al. 2020). The analysis result showed the average annual sun exposure in Sentani Watershed is $62.5 \%$ to $75 \%$. Furthermore, the factor influencing sunlight absorption by sago palms is the cluster density, which blocks light penetration. More factors include the difference in sago palm anatomy, other plants crown covering its growing area, the presence of offshoot/suckers, various petiole lengths, diameter, and height.

\section{Sago palm habitat based on slope gradient}

Sentani Watershed area has varied landforms ranging from a flat plain to hill, and mountain, furthermore, topography plays an important role in determining the speed of surface water in carrying soil particles. Also, one of the factors influencing and controlling the soil formation process is a slope which greatly affects species composition but has no significant effect on their richness (Nepali et al. 2021). This seems possible because the mentioned parameter tends to initiate the formation of either fertile or critical land of any particular area, and the higher the slope gradient, the potential for critical land becomes greater. Dong et al. (2016) stated that slope gradient affects the value of erosion over a zone. Hence, as the gradient increases, soil fertility is reduced, leading to elevated destructive impact force from the surface water onto the soil. The presence of the sago palm landscape in terms of its inclination can be seen in Table 3 and Figure 4 .

Table 3. Distribution of sago palm landscape based on slope

\begin{tabular}{|c|c|c|c|c|c|c|c|c|}
\hline \multirow{2}{*}{$\begin{array}{l}\text { Slope } \\
(\%)\end{array}$} & \multicolumn{6}{|c|}{ Sub-district (ha) } & \multirow[b]{2}{*}{ Total } & \multirow[b]{2}{*}{ Percent (\%) } \\
\hline & Ebungfau & Kemtuk & Sentani & West Sentani & East Sentani & Waibu & & \\
\hline $0-1$ & 176.86 & 27.25 & $1,852.94$ & 78.72 & 243.47 & 562.75 & $2,941.99$ & 37.51 \\
\hline $2-8$ & 334.89 & 222.58 & 254.38 & 171.2 & 555.09 & 451.55 & $1,989.69$ & 25.37 \\
\hline $9-15$ & 252.75 & 171.35 & 30.11 & 164.61 & 324.07 & 415.92 & $1,358.81$ & 17.33 \\
\hline $16-25$ & 131.25 & 140.64 & 22.01 & 175.46 & 274.62 & 339.51 & $1,083.49$ & 13.82 \\
\hline $26-40$ & 3.78 & 31.48 & 5.17 & 106.02 & 110.16 & 170.25 & 426.86 & 5.44 \\
\hline $41-60$ & - & - & - & - & 14.44 & 27.48 & 41.92 & 0.53 \\
\hline Total & 899.53 & 593.30 & $2,164.61$ & 696.01 & $1,521.85$ & $1,967.5$ & $7,842.76$ & 100 \\
\hline
\end{tabular}

Source: Spatial Data Analysis (2020)

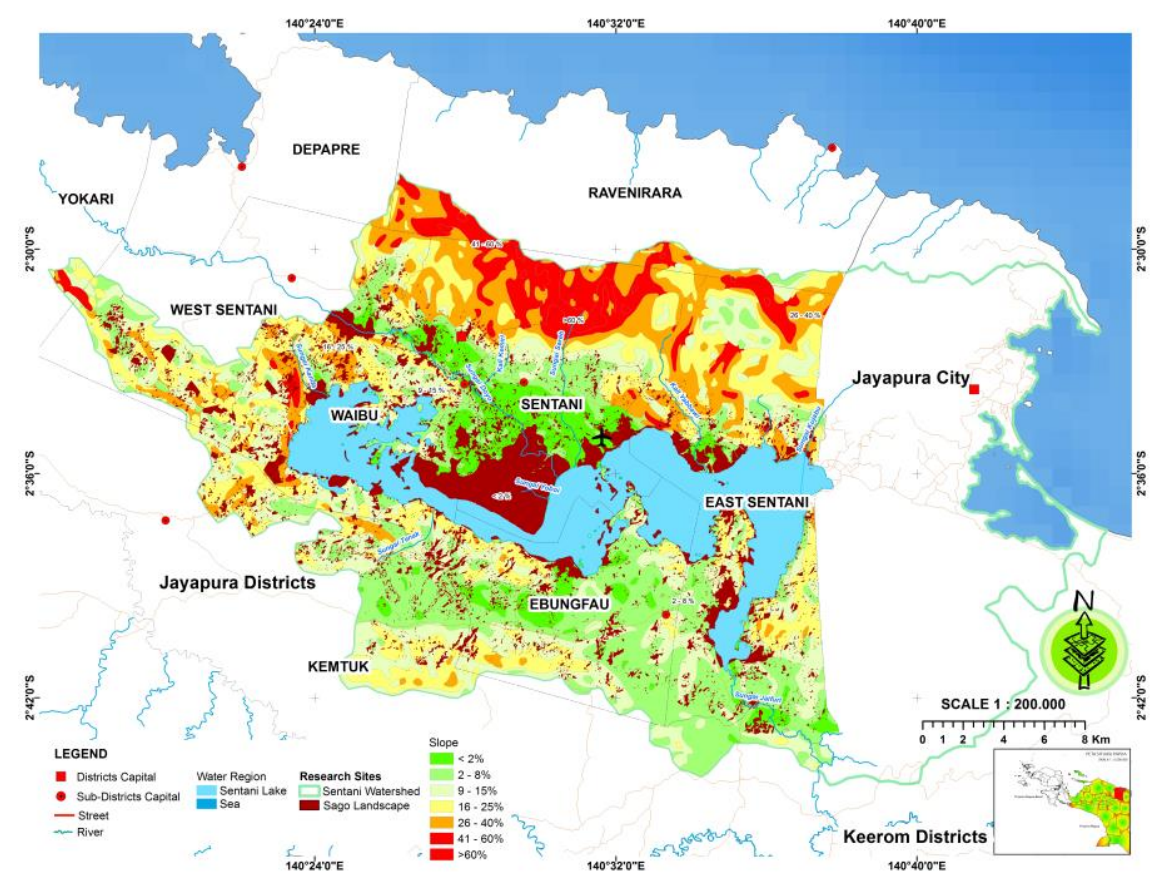

Figure 4. Map of sago landscape based on slope 
Sago forest can be seen in varied gradients starting from flat plain until very steep, while its largest habitat lies in the slope $0-1 \%$ covering 2,941.99 ha, and topographically, Metroxylon sagu Rottb grows well in any flat area. In Sentani Watershed, there is a connection between slope gradient and sago forest as the coverage declines in the steep area (41-60\%) to 41.92 ha. In addition, the slope direction also greatly affects certain plant species. This deals with the aspect of sunlight direction as the exposure has an immediate impact on varied environmental temperatures (Nepali et al. 2021)

Topographically, the sago palm still lives and grows in a non-flat plain (steep to very steep). However, this plant is in form of small clusters which have poor vegetative growth and longer harvest time in certain plots of a site that has a very steep slope. Furthermore, the sago palm landscape surrounding Sentani Lake lies in a flat area, thereby allowing it to receive intense sunlight. The difference in varied environmental temperatures has a strong impact on sago palm growth and distribution (Abbas et al. 2010). Slope gradient is one of the factors influencing soil development caused by the physical and living environments.

\section{Sago palm habitat based on types of soil}

The map with a scale of $1: 250,000$ published by the Centre of Soil Research and Agroclimate (Puslitanak) was used to determine the soil types for sago palm habitat in Sentani Watershed. Notably, this plant lives in certain soils namely litosol, latosol, and podsol, as well as the Mediterranean which is the dominant one. Soil is the supporting factor in sago palm's growth and production (Ehara et al. 2018), hence the habitat's distribution can be seen in Table 4 and Figure 5.

Table 4 shows that most sago palms grow in Mediterranean and podsol soils. The first can be found in the northern \& western part of Sentani Watershed is generated from volcanic parent rocks' decomposition. Furthermore, its solum is slightly dense (1-2 m) and has a slightly acidic to neutral reaction $(\mathrm{pH}$ 5.0-7.0) as well as medium to great soil erodibility. In fact, the sago palm living in this soil forms varied clusters i.e. homogenous and heterogeneous landscape in dry land and swamp habitat, respectively (Irawan et al. 2009). Homogeneity reflects the high rate of sago palm dominance over other plants, while heterogeneity means a low dominance rate.

Table 4. Soil type-based distribution of sago palm landscape

\begin{tabular}{|c|c|c|c|c|c|c|c|c|}
\hline \multirow{2}{*}{ Types of soil } & \multicolumn{6}{|c|}{ Sub-district (ha) } & \multirow{2}{*}{ Total } & \multirow[b]{2}{*}{ Percent (\%) } \\
\hline & Ebungfau & Kemtuk & Sentani & West Sentani & East Sentani & Waibu & & \\
\hline Litosol & - & - & 371.56 & 233.76 & 44.67 & 378.38 & $1,028.37$ & 13.11 \\
\hline Latosol & 190.75 & - & 16.52 & - & 559.87 & - & 767.14 & 9.78 \\
\hline Podsol & 693.68 & 590.30 & 171.19 & - & 116.66 & 540.24 & $2,112.07$ & 26.93 \\
\hline Mediterranean & 15.10 & 3.00 & 1605.34 & 462.25 & 800.65 & $1,048.84$ & $3,935.18$ & 50.18 \\
\hline Total & 899.53 & 593.30 & $2,164.61$ & 696.01 & $1,521.85$ & $1,967.46$ & $7,842.76$ & 100 \\
\hline
\end{tabular}

Source: Soil Map (Puslitanak 1983) and Spatial Data Analysis (2020)

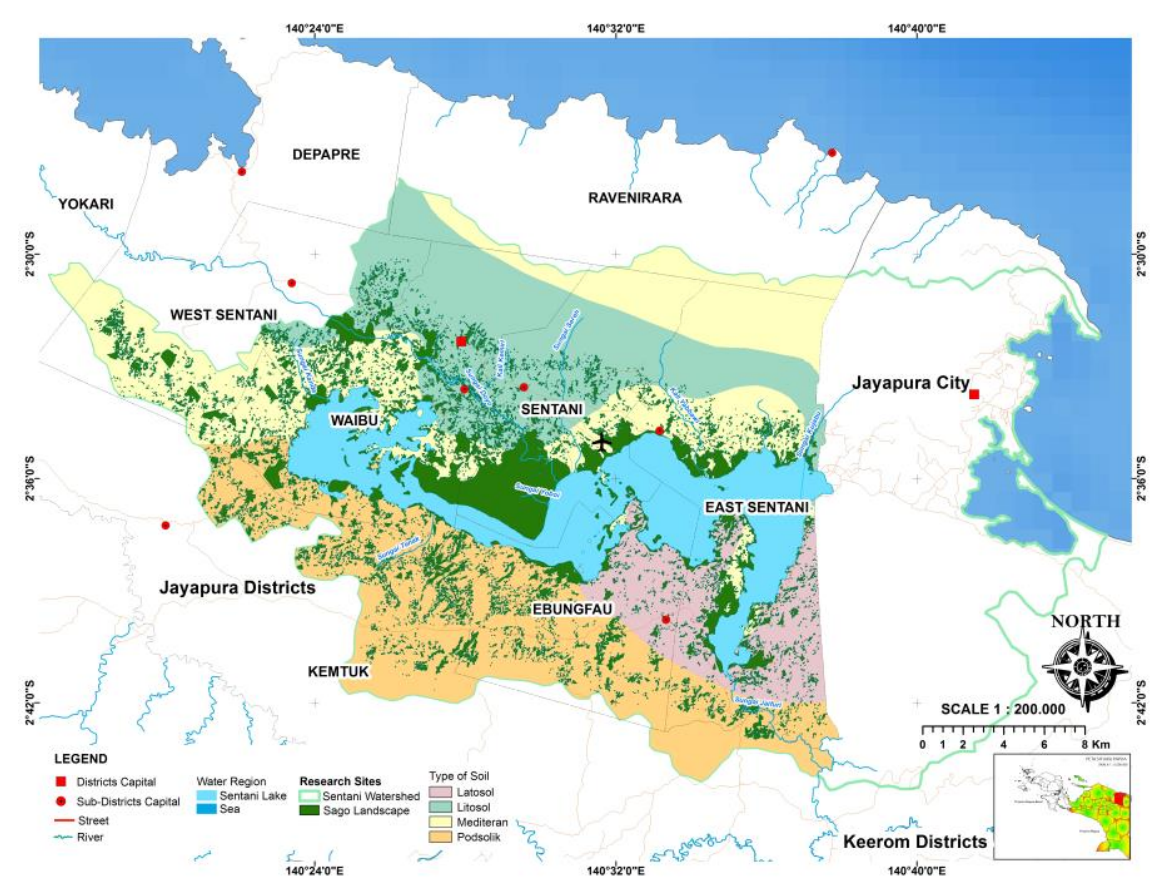

Figure 5. Sago palm landscape map based on types of soil 
Furthermore, the research on sago palm habitat in Sentani and East Sentani Districts shows that the clusters grow in clogged-drainage alluvium plain and very shallow groundwater. In the area close to Sentani Lake, there is mineral soil and light brown peat with varied textures from loamy clay to sandy silt clay. The topography is flat to moderate flat, while the soil is classified as Inceptisole that has groundwater in $100 \mathrm{~cm}$ depth from the surface and falls into the poor quality category. In contrast, sago palm habitat scatters in Waibu Sub-District and grows in varied soil ecosystems directed to the Sentani Lake area which has peat, and to the hilly area that only has very clogged and clogged drainage soil. The textures are varied, ranging from loamy clay, sandy silt clay to loam, while the parent material is derived from alluvium and decayed vegetation which its organic material layer experiences hemic and fibric decomposition. The topography here is flat to moderate flat, moreover, inceptisol in this area has dark brown organic-rich topsoil. Sago palm grows well in inceptisol soil that has very clogged drainage or nonpermanently inundated land. The best environment for sago palm to grow is in a muddy area where its pneumatophores (breathing roots) are not submerged, including dark brownish-yellow clay that is intensively rich in organic material. In addition, the plant grows well provided the area has tidal waves especially the freshwater ones (Ehara 2005).

Sago palm grows in any soil type (Miyamoto et al. 2009), as well as in the upland area that has litosol, latosol, and podsol. For further illustration, podsol soil spreads in the southern part has a wavy topography until hilly slope on a certain elevation of $20-100 \mathrm{~m}$ asl, where more dense solum (1-2 $\mathrm{m}$ ) in varied colors ranged from red to yellow. Its soil reaction is very acidic to acidic which also has strong erodibility and low soil fertility. Sago palm population in this area is in a small cluster and proximity to river flows while being associated with woody vegetation.

\section{Sago palm habitat based on climate}

Climate data explained here covers rainfall, temperature, and moisture, but the first influences water supply level on the land as can be seen in Table 5 .

The largest sago palm habitat is in the area that has rainfall of $1,750 \mathrm{mmyr}^{-1}$, covering $6,846.24$ ha $(87.29 \%)$. According to data published by Indonesia's Meteorological, Climatological, and Geophysical Agency (BMKG) in Jayapura, most sago palms in Sentani Watershed grow in average monthly rainfall ranging from $108.20 \mathrm{~mm}$ in January to $258.10 \mathrm{~mm}$ in November, which in other words, range from 1,494.40 $\mathrm{mm}-2,796.32 \mathrm{~mm} \mathrm{yr}^{-}$ 1. According to Matanubun (2015) in Papua province, the studied plant generally grows in Climate Type B1 that has an average rainfall of $2,118 \mathrm{~mm} \mathrm{yr}^{-1}$. The pattern of rainfall in the Jayapura District shows that the value increases in line with area elevation, hence certain parameters of climate including rainfall and temperature are basic environmental factors contributing to vegetation dynamic (Zhu et al. 2016; Azhar et al. 2018a).

Furthermore, this research also ascertains the effect of sunlight intensity in sago palm habitat in Sentani Watershed, indicating that sunlight intensity partially penetrates the floor of the cluster formed. In particular, the average sunlight intensity measured in the proximity of the sago palm cluster is around 226.48 lux while being around 792.12 lux in the transition area between one cluster to another. In contrast, sunlight intensity measured in an open space reaches $1,642.10$ lux, meaning more than $50 \%$ of the exposure tends not to penetrate the floor area of the plant's cluster. This is because there is a blockage from the forest canopy produced from the close-knit formation of petioles and leaves. In addition, each cluster consists of several individuals that can be in various stages ranging from tree to seedling.

Moreover, the average air temperature under the sago palm cluster during observation time spanning from August - December 2020, was discovered to range from 21.89$22.20^{\circ} \mathrm{C}$. Yet, the data collected from the BMKG station in Jayapura showed the average air temperature ranged from 27.60 to $28.48^{\circ} \mathrm{C}$, meaning the fluctuation of this factor under sago palm stand is relatively narrow or lower compared to the one within a clear area. The supporting optimal temperature for sago palm's growth ranges from $24.5-29^{\circ} \mathrm{C}$, where the lowest is $15^{\circ} \mathrm{C}$ and relative moisture is from 70-90\% (Morrison et al. 2012). Also, air temperature change around the plant generally follows the fluctuation of local temperature conditions that were detected to be on averagely $28.82^{\circ} \mathrm{C}$ in May. This condition lasted for six months and declined until it reached $27.60^{\circ} \mathrm{C}$ in November. In other words, local temperature all through this period decreased around $1.27^{\circ} \mathrm{C}$. This follows the change of season pattern as May is in the Dry Season, while other months until November is already in transition to Rainy Season. This temperature range is essential in influencing plant growth stages, which once low, tends to extend the early vegetative phase. The photosynthetic activity of sago palms is more optimal at a temperature of 25-29 ${ }^{\circ} \mathrm{C}$ (Azhar et al. 2018a)

Table 5. Rainfall-based distribution of sago palm landscape

\begin{tabular}{|c|c|c|c|c|c|c|c|c|}
\hline \multirow{2}{*}{$\begin{array}{c}\text { Rain precipitation } \\
(\mathrm{mm} / \text { year })\end{array}$} & \multicolumn{6}{|c|}{ Sub-district (ha) } & \multirow{2}{*}{ Total } & \multirow{2}{*}{$\begin{array}{c}\text { Percent } \\
(\%)\end{array}$} \\
\hline & Ebungfau & Kemtuk & Sentani & West Sentani & East Sentani & Waibu & & \\
\hline 1750 & 899.53 & 419.22 & $2,164.61$ & 286.18 & $1,521.85$ & $1,554.85$ & $6,846.24$ & 87.29 \\
\hline 2500 & - & 174.08 & - & 409.83 & - & 412.61 & 996.52 & 12.71 \\
\hline Total & 899.53 & 593.30 & $2,164.61$ & 696.01 & $1,521.85$ & $1,967.46$ & $7,842.76$ & 100 \\
\hline
\end{tabular}

Source: Spatial Data Analysis (2019) 


\section{Sago palm habitat based on the distance of the river and lake}

In general, 11 rivers are flowing through Sentani Watershed and all of them finally discharge into Sentani Lake. Therefore, sago palm scatters along the river basins and lakeshores in a pattern that forms the plant's habitat. For example, there are swampy, transition, and dry habitats that have permanently and temporarily waterlogged, as well as dry \& non-inundated areas, respectively. Despite this, the rivers' distance to sago palm habitat can be seen in Table 6.

The largest sago palm habitat is in the Doyo River that covers 207.47 ha $(30.85 \%)$, while the Kehiran river occupies the second largest area $(28.19 \%)$. Also, the Sereh River has the smallest area as this only covers 6.07ha. The sago palm's natural habitat is found in drainage areas and muddy rivers, including a muddy area that sometimes dries gradually (Singhal et al. 2008; Ehara et al. 2009).
Furthermore, the habitat's condition along the river basins can be defined as temporarily waterlogged and/or dry, indicating that it is occasionally submerged. Temporarily waterlogged means that this habitat has water submersion when it rains and/or becomes submerged for a while i.e. between one to two weeks or until one month, depending on the precipitation's intensity.

Sago palm has optimal growth in the wetland, because this condition provides a large amount of water support for it (Ehara et al. 2018). However, the continual waterlogged condition will influence the photosynthesis capacity to be less optimal. In fact, Sentani Lake is the commonest place for Metroxylon sagu Rottb (Figure 5) to grow, meaning the plant has adapted well to either waterlogged or dry habitat. The distance between the lake and the sago palm landscape can be seen in Table 7 and Figure 6.

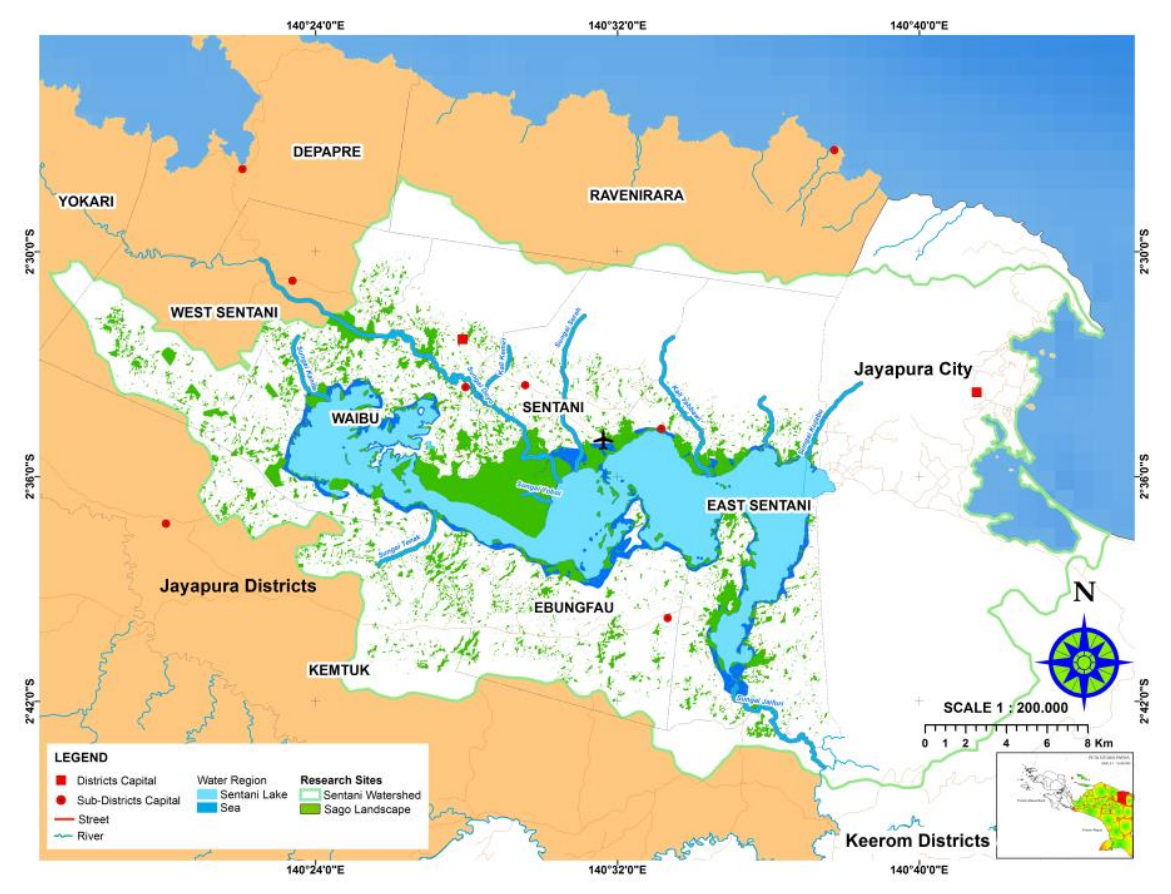

Figure 6. Map of sago palm landscape based on the distance of river and lake

Table 6. Distances between the rivers and the sago palm habitat

\begin{tabular}{lcccl}
\hline Names of river & Length of river $(\mathbf{m})$ & Sago forest coverage * (ha) & Percent $(\%)$ & Sub-district \\
\hline Doyo River & 17,783 & 207.67 & 30.85 & West Sentani, Waibu \\
Jaifuri River & 9,443 & 22.45 & 3.34 & East Sentani \\
Kanda River & 4,031 & 50.38 & 7.48 & West Sentani, Waibu \\
Kehiran River & 7,512 & 189.77 & 28.19 & Sentani \\
Kujabu River & 4,619 & 27.06 & 4.02 & East Sentani \\
Sentani River & 5,152 & 15.02 & 2.23 & Sentani \\
Sereh River & 3,310 & 6.07 & 0.90 & Sentani \\
Tenak River & 4,255 & 25.78 & 3.83 & Kemtuk, Waibu \\
Yoboi River & 1,562 & 65.89 & 9.79 & Sentani \\
Kemiri River & 3,079 & 15.25 & 2.27 & Sentani \\
Yabbawi River & 8,632 & 47.76 & 7.10 & Sentani \\
Total & & 673.10 & 100 & \\
\hline
\end{tabular}

Note: *Distance 0-200 meters from the body of river to sago palm habitat. Source: Spatial Data Analysis (2020) 
Table 7. Distance between Sentani Lake and the sago palm landscape

\begin{tabular}{lccl}
\hline Distance & $\begin{array}{c}\text { Sago } \\
\text { forest } \\
\text { coverage } \\
\text { (ha) }\end{array}$ & $\begin{array}{c}\text { Percent } \\
(\%)\end{array}$ & \multicolumn{1}{c}{ Sub-district } \\
\hline $0-100 \mathrm{~m}$ & 58.72 & 2.32 & Waibu, Sentani, East Sentani \\
$101-200 \mathrm{~m}$ & 641.23 & 25.32 & Waibu, East Sentani \\
$201-300 \mathrm{~m}$ & $1,832.11$ & 72.36 & Sentani \\
Total & $2,532.06$ & 100 & \\
\hline
\end{tabular}

Note: *Distance 100-300 meters from the lake to sago palm habitat(s). Source: Spatial Data Analysis (2020)

Significantly, the range of surface water and ground water's depth is prominent in determining sago palm's growth. Based on the result of distance measurement (201$300 \mathrm{~m}$ ) from lakeshores to sago palm landscape, a homogenous cluster covers $1,832.11$ ha $(72.36 \%)$. The relief condition of Sentani Watershed varying from flat to hill and mountain causes different hydrology conditions compared to other areas. Sago palm habitat in the lakeshore possesses a flat relief condition as this can be seen from its slope gradient $(0-2 \%)$. It hydrologically has temporarily waterlogged to dry habitats, where the surface water of the first type is $20 \mathrm{~cm}$ in the dry season and $50-70 \mathrm{~cm}$ in the rainy season. Similarly, the second has $10-15 \mathrm{~cm}$ surface water depth which uses 1-3 months to dry. Sago palm habitats in Papua New Guinea lies in the alluvial plain, flood plain swamps, back swamps, and coastal areas (Ehara 2018).

Water plays an important role in the growth of sago palm, by acting as the nutrient source and dissolvent. Hence, this plant depends heavily on the way the essential nutrients and water in the soil are provided (Azhar et al. 2020). The common overflowing water condition in swampy areas is less beneficial for the growth as it leads to the soil around roots being poorly aerated. Soil aeration is closely linked to the existing air content which its level of availability determines the $\mathrm{CO}_{2}$ quantity formed from the bottom decomposition of organic materials caused by microbes. Significantly, water is one of the essential components affecting the plant's growth because as the deficit occurs, the leaves continually shrink in size. This factor also contributes to the formation of leaf structure that plays a role in the metabolism process which can become reduced when water is deficient. Therefore, the groundwater depth needs to be maintained for sago palms as well as to control the surface water. According to Azhar et al. 2018b, sago palm grows well in the tidal landscape especially the freshwater area.

In conclusion, the sago palm landscape in Sentani Watershed covers 7,842.76 ha, such that the forest distributes in 6 (six) sub-districts i.e. Ebungfau, Kemtuk, Sentani, West Sentani, East Sentani, and Waibu. Its largest habitat can be seen in the elevation of $0-100 \mathrm{~m}$ asl, covering $4,385.63$ ha $(55.92 \%)$. Meanwhile, the smallest which is located in $401-450 \mathrm{~m}$ asl has an 11.39 ha $(0.15 \%)$ total area. The habitat of the plant is mostly found in
Mediterranean soil which receives a precipitation rate of $1,750 \mathrm{~mm} \mathrm{yr}^{-1}$. Furthermore, the largest is found around Sentani Lake (between 201\& $300 \mathrm{~m}$ ) and in the Doyo River's bank, ranging from $0-200 \mathrm{~m}$. The suitable location for sago palm habitat based on these environmental indicators is the Sub-districts of West Sentani, Waibu, Sentani, and East Sentani.

\section{ACKNOWLEDGEMENTS}

The authors are grateful to LPDP (Indonesian Government Scholarship Institution) for the fund provided, as well as to the Faculties of Forestry in Gadjah Mada University, Yogyakarta, Indonesia and the University of Papua, Jayapura, Indonesia. The authors are also grateful to all parties that helped in completing this research.

\section{REFERENCES}

Abbas B, Ihwan T, Munarti. 2020. Genetic diversity of sago palm (Metroxylon sagu) accessions based on plastid cpDNA matK gene as DNA barcoding. Biodiversitas $21 \quad$ (1): 219-225. DOI:10.13057/biodiv/d210128

Abbas B, Yanuarius R, Muhammad HB, Sudarsono, Memen S, Hiroshi E. 2010. Genetic diversity of sago palm in Indonesia based on chloroplast DNA (cpDNA) markers. Biodiversitas 11 (3): 112-117. DOI: $10.13057 /$ biodiv/d110302

Anugoolprasert O, Shina K, Hitoshi N, Masafumi S, Hiroshi E. 2012. Effect of low $\mathrm{pH}$ on the growth, physiological characteristics and nutrient absorption of sago palm in a hydroponic system. Plant Prod Sci 15 (2): 125-131. DOI: 10.1626/pps.15.125.

Azhar A, Daigo M, Hitoshi N, Koki A, Mai T, Saeka U, Rena T, Barahima A, Hiroshi E. 2020. Sago Palm (Metroxylon sagu Rottb.) Response to drought condition in terms of leaf gas exchange and chlorophyll a fluorescence. Plant Prod Sci 24 (1): 65-72. DOI: 10.1080/1343943x.2020-1794914

Azhar A, Daigo M, Hitoshi N, Hiroshi E. 2018a. Photosynthesis of sago palm (Metroxylon sagu Rottb.) seedling at different air temperatures. MDPI Agric 8 (4): 1-10. DOI: 10.3390/agriculture8010004.

Azhar A, Daigo M, Hitoshi N, Hiroshi E. 2018b. Evaluating sago palm (Metroxylon sagu Rottb.) photosynthetic performance in waterlogged conditions: utilizing pulse-amplitude modulated (PAM) fluorometry as a waterlogging stress indicator. J Saudi Soc Agric Sci 19 (1): 3742. DOI: $10.1016 /$ j.jssas.2018.05.004

Bantacut T. 2011. Sago: Resource for staple food diversification (Sumberdaya untuk penganekaraman pangan pokok). Food Journal (Jurnal Pangan) 20 (1): 27-40. DOI: 10.33964/jp.v20i1.6

Birhane E, Haregeweini A, Ayele AF, Hadgu H, Mewcha AG, Hailemariam GW, Negasi S. 2019. Land use land cover changes along topographic gradients in Hugumburda National Forest priority area, Northern Ethiopia. Remote Sens Appl: Soc Environ 13: 61-68. DOI: 10.1016/j.rsase.2018.10.017.

BenDor TK, Danielle S, Sierra CW, Lydia O. 2017. A research agenda for ecosystem services in American environmental and land use planning. Cities 60: 260-271. DOI: 10.1016/j.cities.2016.09.006.

Dong X, Ding S, Long L, Deng Y, Wang Q, Wang S, Cai C. 2016. Effects of collapsing gully erosion on soil qualities of farm fields in the hilly granitic region of South China. J Integr Agric 15 (12): 2873-2885. DOI: 10.1016/S2095-3119(16)61348-5.

Ehara H, Toyoda Y, Johnson DV. 2018. Sago palm: Multiple contributions to food security and sustainable livelihoods. Singapore: Springer Nature.

Ehara H, Wikanya P, Hiroyuki S, Hitoshi N. 2009. Role of root to avoid salt stress in sago palm (Metroxylon sagu Rottb.). International Symposium Root Research and Applications (RootRAP), 2-4 September 2009. Boku, Vienna, Austria 
Ehara H. 2005. Geographical distribution and specification of Metroxylon palms. Jpn J Trop Agr 50, 299-233. DOI: 10.11248/jsta1957.50.229.

El-Hendawy S, Nasser A, Salah E, Yahya R, Majed A, Yaser HD, Wael H, Urs S. 2019. Combining biophysical parameters, spectral indices and multivariate hyperspectral models for estimating yield and water productivity of spring wheat across different agronomic practices. Plos one 14 (3): 1-26. DOI: 10.1371/ journal.pone.0212294

Irawan AF, Yoshinori Y, Akira M, Tetsushi Y, Jong FS. 2009. Characteristics of suckers from sago palm (Metroxylon sagu Rottb.) grown in different soil types in Tebing Tinggi Island, Riau, Indonesia Trop Agr Develop 53 (4): 103-111. DOI: 10.11248/jsta.53.103.

Kindu M, Schneider T, Teketay D, Knoke T. 2013. Land use/land cover change analysis using object-based classification approach in Munessa-Shashemene landscape of the Ethiopian highlands. J Remote Sens 5 (5): 2411-2435. DOI: 10.3390/rs5052411.

Kumar P, Manmohan D, Amey K, AK Pandey. 2021. Temporal dynamics change of land use/land cover in Jhansi district of Uttar Pradesh ove past 20 years using Landsat TM, ETM+ and OLI sensors. Remote Sens Appl: Soc Environ 23:1-9. DOI: 10.1016/j.rsase.2021.100579

Lim LWK, Chung HH. 2020. Salt tolerance research in sago palm (Metroxylon sagu Rottb.): Past, present and future perspectives. Pertanika J Trop Agric Sci 43 (2): 91-105.

Li Q, Xueyi S, Qingqing W. 2020. Exploring suitable topographical factor conditions for vegetation growth in Wanhuigou catchment on the Loess Plateau, China: A new perspective for ecological protection and restoration. Ecol Eng 158: 106053. DOI: 10.1016/j.ecoleng.2020.106053.

Liu S, Xing L, Dan C, Yuanqiang D, Hanyu J, Liangpeng Z, Qi C, Xiaodong H. 2020. Understanding Land use/Land cover dynamics and impacts of human activities in the Mekong Delta over the last 40 years. Glob Ecol Conserv 22: 1-20. DOI: 10.1016/j.gecco.2020.e00991.

Matatula J, Erny P, Satyawan P, Ronggo S. 2019. Spatial distribution of salinity, mud thickness and slope along mangrove ecosystem of the coast of Kupang District, East Nusa Tenggara, Indonesia. Biodiversitas 20 (6): 1624-1632. DOI: 10.13057/biodiv/d200619.

Matanubun H. 2015. Folk taxonomy of sago palm varieties around Sentani Lake, Jayapura, Papua Province, Indonesia. Proceedings of the $12^{\text {th }}$ International Sago Symposium. Manokwari, 15-16 September 2015.

Miyamoto E, Sachi M, Ho A, Ken-ichi K, Foh-shoon J, Akira W. 2009. Effect of sago palm (Metroxylon sagu Rottb.) cultivation on the chemical properties of soil and water in tropical peat soil ecosystem. Nutr Cycl Agroecosyst 85 (2): 157-167. DOI: 10.1007/s10705-0099255-X.

Miyazaki A, Yoshinori Y, Kazuki O, Hardaning P, Ray SG, Yulius BP, Jermia L. 2007. Leaf photosynthetic rate in sago palms (Metroxylon sagu Rottb.) grown under field conditions in Indonesia. Jpn J Trop Agr 51 (2): 54-58. DOI: 10.11248/jsta1957.51.54

Morrison C, Isaac R, Dick W. 2012. Conservation and management of the endangered Fiji sago palm, Metroxylon vitiense, in Fiji. Environ Manag 49 (5): 929-941. DOI: 10.1007/s00267-012-9836-3.

Muhidin, Sitti L, Syamsu A, Teguh W. 2016. Comparative studies on different agroecosystems base on soil physicochemical properties to development of sago palm on dryland. Intl J Chem Tech Res 9 (8): 511-518.

Nepali BR, John S, Chitra BB. 2021. Impacts of slope aspects on altitudinal species richness and species composition of Narapani-
Masina landscape, Arghakhanchi, West Nepal. J Asia-Pac Biodivers 1-10. DOI: 10.1016/j.japb.2021.04.005.

Osunmadewa BA, Worku ZG, Elmar C, Olabinjo CA. 2018. Spatiotemporal monitoring of vegetation phenology in the dry sub-humid region of Nigeria using time series of AVHRR NDVI and TAMSAT datasets. Open Geosci 10 (1): 1-11. DOI: 10.1515/geo-2018-0001

Riyanto R, Imam W, Barahima A. 2018. Morphology, growth and genetic variations of sago palm (Metroxylon sagu Rottb) seedlings derived $\begin{array}{lllll}\text { from seeds. Biodiversitas } 19 & \text { (2): 682-688. DOI: }\end{array}$ 10.13057/biodiv/d190241.

Saadat H, Jan A, Robert B, Forood S, Mohammad N, Sasan AE. 2011. Land use and land cover classification over a large area in Iran based on single data analysis of satellite imagery. ISPRS J. Photogrammetry Remote Sens 66 (5): 608-619. DOI: 10.1016/j.isprsjprs.2011.04.001

Singhal RS, John FK, Sajilata MG, Agnieszka K, Charles JK, Putri FA. 2008. Industrial production, processing and utilization of sago palmderived product. Carbohidrate Polymers 72 (1): 1-20. DOI: 10.1016/j.carbpol.2007.07.043

Sulistyo B. 2017. The accuracy of the outer boundary delineation of coral reef area derived from the analyses of various vegetation indices of satellite Landsat thematic mapper. Biodiversitas 18 (1): 351-358. DOI: 10.13057/biodiv/d180146.

Spruce J, John B, Ibrahim NM, Raghavan S, Venkat L. 2020. Mapping land use land cover change in the Lower Mekong Basin from 1997 to 2010. Front Environ Sci 19 (8): 1-31. DOI: 10.3389/fenvs.2020.00021.

USGS 2017. Landsat collection 1 level 1 product definition in: survey, D.o.t.I.U.S.G. (ed) USGS, Sioux Falls, South Dakota, USA.

Warnasuriya TWS, Kumara PB, Alahacoon N. 2014. Mapping of selected coral reffs in southern, Srilangka using remote sensing methods. Sri Langka J. Aquat Sci 19: 41-55. DOI: 10.4038/sljas.v19i0.7450

Wondie M, Demel T, Assefa MM, Werner S. 2012. Relationship between topographic variables and land cover in the Simen Mountains National Park, a World Heritage site in Nothern Ethiopia. Int J Remote Sens Appl 2 (2): 36-43.

Xu X, Suravi S, Hammad G, Murali KG, Baktiar NS, Atul KJ. 2020. Dynamics and drivers of land use and land cover changes in Bangladesh. Reg Environ Change 20 (54): 1-11. DOI: 10.1007/s10113-020-01650-5

Yamamoto Y. 2011. Starch productivity of sago palm and the related factors. In: Siregar IZ, Sudaryanto T, Ehara H, Suwardi, Lubis I, Ardie SW (eds) Proceeding of sago for food security, bio-energy, and industry, from research to market. The $10^{\text {th }}$ International Sago.

Yater T, Herman WT, Cipta M, Baharima A. 2019. A comparative study of phenotypes and starch production in sago palm (Metroxylon sagu) growing naturally in temporarily inundated and noninundated areas of South Sorong, Indonesia. Biodiversitas 20 (4): 1121-1126. DOI: 10.13057/biodiv/d200425.

Zhu, Z, Piao S, Myneni RB, Huang M, Zeng Z, Canadell JG, Ciais P, Sitch S, Friedlingstein P, Arneth A, Cao C, Cheng L, Kato E, Koven C, Li Y, Lian X, Liu Y, Liu R, Mao J, Pan Y, Peng S, Penuelas J, Poulter B, Pugh TAM, Stocker BD, Viovy N, Wang X, Wang Y, Xiao Z, Yang H, Zaehle S, Zeng N. 2016. Greening of the earth and its drivers. Nat Clim Change 6 (8): 791-795. DOI: 10.1038/nclimate3004.

Zhu F. 2019. Recent advances in modifications and application of sago starch. Food Hydrocolloids 96: 412-423. DOI: 10.1016/j.foodhyb.2019.05.035 